\title{
Akseptabilitas Draf Kriteria Baru Penentuan Kalender Hijriah Menurut Ahli Falak di Indonesia
}

\author{
Ahmad Fadholi \\ Fakultas Syariah dan Ekonomi Islam \\ IAIN Syaikh Abdurrahman Siddik Bangka Belitung, Indonesia \\ jessarung75@gmail.com
}

\begin{abstract}
In 2015 AD, 2016 AD, 2017 and 2017 there was a new discussion about the draft of new criteria for the determination of the Islamic calendar in Indonesia, namely the draft MUI criteria and the new draft criteria MABIMS, with the criteria of 3 degrees hilal height and 6.4 degree elongation. This criterion is deliberately made for the benefit and mutual agreement for the unification of the hijri calendar in Indonesia. It is hoped that the experts of the Islamic organizations in Indonesia will give their views and attitudes to the draft of new criteria to harmonize the criteria for "hilal visibility" which will be used as a reference and guideline for the determination of the beginning of the Islamic month. This study shows that both the rukyat school and the reckoning school as a whole are acceptable for the draft MUI criteria and the new draft MABIMS as the determination of the Islamic calendar in Indonesia. However, overall the distribution of the scores of the two schools is categorized as moderate, so there are those who agree, disagree, and do not agree with the draft criteria. Overall, the two new draft criteria have the opportunity to be applied in Indonesia. To realize this, it is necessary to have a dialogue between Islamic mass organizations, astronomers and fiqh experts, as well as the government as policy makers.
\end{abstract}

Keywords: Acceptability, New Criteria, Islamic Calendar

Abstrak

Pada tahun 2015 M, 2016 M, 2017 dan 2017 terdapat wacana baru pembahasan tentang draf kriteria baru penentuan kalender hijriah di Indonesia, yaitu draf kriteria MAUI serta draf kriteria baru MABIMS, dengan kriteria tinggi hilal 3 derajat dan elongasi 6,4 derajat. Kriteria ini sengaja dibuat untuk kepentingan dan kesepakatan bersama guna penyatuan kalender hijriah di Indonesia. Ahli falak Ormas Islam di Indonesia diharapkan memberikan pandangan dan sikap terhadap draf kriteria baru sebagai penyelarasan kriteria "visibilitas hilal" yang nantinya sebagai acuan dan pedoman untuk penentuan awal bulan Hijriah. 
Kajian ini menunjukkan bahwa, mazhab rukyat maupun mazhab hisab secara keseluruhan akseptabel (positif) terhadap draf kriteria MUI maupun draf kriteria baru MABIMS sebagai penentuan kalender hijriah di Indonesia. Namun, secara keseluruhan penyebaran frekuensi skor kedua mazhab dikategorikan sedang, sehingga ada yang setuju, kurang setuju, dan belum setuju terhadap draf kriteria tersebut. Secara keseluruhan, kedua draf kriteria baru memiliki peluang untuk diterapkan di Indonesia. Untuk merealisasikannya perlu dilakukan dialog antara ormas Islam, ahli falak, ahli astronomi, serta ahli fikih, juga tentunya pemerintah sebagai pemangku kebijakan.

Kata Kunci: Akseptabilitas, Kriteria Baru, Kalender Hijriyah

\section{A. Pendahuluan}

Penetapan awal bulan Hijriah di Indonesia sampai saat ini masih terjadi perbedaan, terutama untuk penetapan puasa Ramad\}an, Idul Fitri, dan Idul Adha. Perbedaan ini terjadi karena belum ada kesepakatan dan kesepahaman terhadap kriteria visibilitas hilal. Pemerintah (Kementerian Agama) berupaya dengan berbagai cara untuk mencari titik temu melalui seminar, lokakarya, pelatihan, dan pertemuan, baik di dalam negeri maupun luar negeri. ${ }^{1}$

Pembahasan tentang draf kriteria baru visibilitas hilal atau imkan rukyat telah dibahas pada pertemuan tingkat nasional di Jakarta pada Jum'at Kliwon s/d Sabtu Legi, 14-15 Agustus 2015 M/ 29-30 Syawal 1436 H bertajuk "Penyatuan Metode Penetapan Awal Ramadłan, Syawal, dan Z|ulhijjah” oleh Kementerian Agama RI (Pemerintah) dengan Majelis Ulama Indonesia (MUI) bersama ormas-ormas Islam se-Indonesia. Kegiatan itu ditindaklanjuti dengan pertemuan para pakar astronomi pada Jum'at Pahing, 21 Agustus 2015 M/ 6 Z|ulqa'dah 1436 H di Jakarta. Agenda utamanya adalah membahas penentuan kriteria awal bulan hijriah, yang hasilnya akan disampaikan kepada MUI sebelum musyawarah nasional 2015 M. Adapun hasil usulan draf "Kriteria MUI" yaitu tinggi hilal 3 derajat, elongasi 6,4 derajat, dijadikan sebagai pedoman dalam penentuan awal bulan hijriah. ${ }^{2}$

1 Slamet Hambali, "Fatwa Sidang Isbat dan Penyatuan Kalender Hijriah", (Makalah Lokakarya Internasional dan Call for Paper IAIN Walisongo Fakultas Syariah, Semarang, 12-13 Desember 2012), 8-9.

2 Thomas Djamaluddin,"Naskah Akademik Usulan Kriteria Astronomis Penentuan Awal Bulan Hijriyah“, diakses 26 Septamber 2016, http//tdjamaluddin.wodpres. 
Selanjutnya pada pertemuan tingkat regional di Malaysia, Muzakarah Menteri Agama Brunei Darussalam, Indonesia, Malaysia, dan Singapura (MABIMS) pada Selasa Wage s/d Kamis Legi, 2-4 Agustus 2016 M/ 27 Syawal s/d 1 Z|ulqa'dah 1437 H menghasilkan usulan draf "Kriteria baru MABIMS", yakni tinggi hilal 3 derajat, elongasi 6,4 derajat, dengan parameter jarak elongasi (lengkungan) adalah dari pusat Bulan keMatahari. ${ }^{3}$ Kriteria tersebut sebagai koreksi atas kriteria imkan rukyat MABIMS dari ketinggian hilal 2 derajat dengan jarak Bulan-Matahari 3 derajat dengan umur bulan 8 $\operatorname{jam}^{4}$

Kedua draf kriteria baru (MUI dan MABIMS) tersebut diharapkan menjadi solusi alternatif untuk penyatuan kalender hijriah di Indonesia khususnya, dan umumnya di kawasan Asia Tenggara. Sebelum draf kriteria digunakan dan diterapkan, terlebih dahulu perlu adanya kesepahaman pendapat dari ormas-ormas Islam di Indonesia terhadap penetapannya. Untuk mengetahui kesepahaman pendapat tersebut dibutuhkan informasi yang bersumber dari pandangan, sikap, dan kebijakan setiap ormas Islam di Indonesia terhadap draf kriteria baru.

Kesepahaman pendapat ini sangat urgen diketahui dan diadakan, mengingat salah satu fakta dari perbedaan penetapan awal bulan hijriah di Indonesia adalah beragamnya pendapat ormas Islam tentang penetapannya. Kalender Islam ${ }^{5}$ yang beredar dan berkembang di masyarakat juga beragam. ${ }^{6}$ Kesepahaman ini perlu diketahui, dikarenakan masing-masing ormas dan golongan-golongan serta jama'ah-jama'ah Islam di Indonesia memiliki sistem dan kriteria yang berbeda-beda pada penetapannya (hisab, rukyat, dan imkan rukyat).

${ }^{3}$ Thomas Djamaluddin,"Menuju Kriteria Baru MABIMS Berbasis Astronomi“, diakses 26 September 2016, http//tdjamaluddin.wodpres.

${ }^{4}$ Kementerian Agama Republik Indonesia, Almanak Hisab Rukyat, (Jakarta: Direktorat Jenderal Pembinaan Kelembagaan Agama Islam, 1998/1999), 43.

5 Pemakaian nama "Kalender Islam" disini karena dimensi kalender yang menjadi konsep penetapan awal bulan didasarkan dari nassyari'ah bukan dari dimensi sains murni. Ini salah satunya terlihat dari produk baru yang ditawarkan dilandasi konsep visibilitas hilal (imkanu rukyat) yang merupakan tafsiran dari berbagai nas, seperti hadis perintah melihat hilal oleh Nabi.

${ }^{6}$ Seperti Kalender Muhammadiyah, Almanak PBNU, Taqwim Standar Indonesia, Taqwim MABIMS, Almanak Islam PERSIS, Menara Kudus, Kalender LDII, dan Kalender Hijri Syamsi (Ahmadiyah). Lihat Pedoman Hisab Rukyat Kementerian Agama RI. 


\section{| AHMAD FADHOLI | Akseptabilitas Draf Kriteria Baru...}

\section{B. Draf kriteria baru penentuan kalender hijriah di indonesia}

Draf kriteria baru sebagai penentuan kalender hijriah di Indonesia, disikapi secara berbeda oleh ahli falak ormas Islam di Indonesia. Hal ini disebabkan karena keyakinan, fanatisme, juga ideologi. Jika dilihat dalam skema besar sistem kenegaraan, ini bisa dikategorikan sebagai salah satu isu yang masuk pada persoalan hubungan antara negara dan agama. Lebih tepatnya, bagaimana negara menerapkan sebuah peraturan yang berkaitan dengan kehidupan keagamaan di Indonesia.

Sebagaimana dikemukakan, bahwa akseptabilitas terhadap draf kriteria baru sebagai penentuan kalender Hijriah oleh ahli falak ormas Islam di Indonesia, bermazhab rukyat dan bermazhab hisab mempunyai kecenderungan akseptabilitas ke arah yang positif terhadap draf kriteria MUI maupun draf kriteria baru MABIMS, baik secara keseluruhan, maupun secara kelompok (mazhab hisab dan rukyat). Akseptabilitas draf kriteria MUI, rata-rata akseptabilitas kedua mazhab berada di titik tengah skala dengan (54) menunjukkan rerata $(57,933)$ untuk mazhab rukyat dan $(57,436)$ untuk madzab hisab, berarti kedunya mempunyai kecenderungan akseptabilitas ke arah yang positif dengan selisih $(0,497)$. Sedangkan akseptabilitas draf kriteria baru MABIMS menunjukkan bahwa akseptabilitas kedua mazhab memiliki selisih $(5,231)$ dengan rerata untuk mazhab rukyat $(60,590)$ dan mazhab hisab $(55,359)$. Meskipun selisih 5 poin, kedua mazhab tersebut mempunyai kecenderungan akseptabilitas ke arah yang positif.

Berdasarkan hasil dari distribusi skor ahli falak bermazhab hisab maupun ahli falak bermazhab rukyat lebih didominasi pada kategori sedang. Namun, juga terdapat subyek yang tergolong kategori tinggi terhadap draf kriteria MUI dan draf kriteria baru MABIMS. Artinya terdapat peluang yang cukup atas kedua draf kriteria baru yang ditawarkan. Peluang tersebut diperkuat dengan adanya responden yang berada pada kategori tinggi. Keberagaman perbedaan atas jawaban subyek kedua mazhab terhadap akseptabilitas draf kriteria MUI dan draf kriteria baru MABIMS, disebabkan beberapa faktor yang mempengaruhi yang paling terlihat adalah setiap ahli falak ormas Islam memiliki pedoman sendiri (rukyat atau hisab) dalam menetapkan awal bulan Hijriah, terutama awal Ramad;an, Idul Fitri, dan Idul Adha.?

${ }^{7}$ Ahmad Izzuddin, Fiqh Hisab Rukyat di Indonesia (Menyatukan NU dan Muhammadiyah dalam Penentuan Awal Ramadhan Idul Fitri dan Idul Adha, (Jakarta: Erlangga, 2007), 59. 
Ini menunjukkan bahwa akseptabilitas dikalangan ahli falak yang bermazhab hisab dan ahli falak bermazhab rukyat terhadap draf kriteria MUI dan draf kriteria baru MABIMS. Hal ini berarti kedua ahli falak mazhab hisab dan rukyat mempunyai niatan untuk bersatu dalam mengawali dan mengakhiri bulan $\operatorname{Ramad}$ \}an, namun hingga saat ini belum tercapai kesepakatan. Persoalan ini disebabkan oleh kepercayaan masing-masing ahli falak yang bermazhab, karena memiliki pedoman kriteria dalam penetapan. ${ }^{8}$

Kedua pedoman (hisab dan rukyat) tersebut seharusnya digabungkan sebagai verifikasi atas rukyat dan hisab atau sebalikya. Untuk itu perlu bersinergi dalam pelaksanaan observasi, guna menghasilkan data yang akurat sesuai dan standar sebagai pedoman penentuan awal bulan Hijriah. ${ }^{9}$ Dengan adanya kriteria akan memperkecil problem perbedaan prinsip seperti hisab, rukyat, dan matlak secara syar'i.

\section{Peran Negara sebagai pemersatu}

Disinilah peran negara (pemerintah) sebagai penentu keputusan (sidang isbat) yang bertujuan untuk memperkecil perbedaan serta mengakomudir pendapat dari berbagai ormas Islam. ${ }^{10}$ Namun, tentunya perlu ada kriteria visibilitas hilal sebagai pedoman dalam penentuan kalender Hijriah untuk mempersatukan antara mazhab hisab dan rukyat, untuk terwujudnya persatuan umat Islam di Indonesia. ${ }^{11}$

Pemerintah telah melakukan berbagai upaya untuk mennyatukan perbedaan awal bulan Hijriah di Indonesia, dengan ditandainya terbentuknya Badan Hisab Rukyat (sekarang Tim Falakiah). Dengan terbentuknya Tim Falakiah yang anggotanya terdiri dari berbagai ormas Islam dan para ahli falak dan astronomi, adalah langkah nyata pemerintah untuk penyatuan awal bulan Hijriah. Maka dengan terbentuknya Tim Falakiah yang mempunyai fungsi diantaranya, memberikan saran atau masukan yang berkaitan dengan

${ }^{8}$ Susiknan Azhari, "Gagasan Menyatukan Umat Islam Indonesia”, Ahkam: Jurnal Ilmu Syariah 15 (2015), 253.

9 Departemen Agama, Almanak Hisab Rukyat, (Jakarta: Direktorat Pembinaan Badan Peradilan Agama Islam, 1998/1999), 42.

${ }^{10}$ Rosyadi, Matlak Global dan Ragional (Studi Tentang Keberlakuan Rukyat Memurut Fikih dan Astronomi), Disertasi tidak diterbitkan, (Semarang: IAIN Walisongo, 2012), 2.

11 Susiknan Azhari, "Penyatuan Kalender Islam Satukan Semangat Membangun Kebersamaan Umat", (Makalah Lokakarya Internasional dan Call for Paper IAIN Walisongo Fakultas Syariah, Semarang, 12-13 Desember 2012), 5. 


\section{| AHMAD FADHOLI | Akseptabilitas Draf Kriteria Baru...}

hisab dan rukyat kepada Menteri Agama, sebagai bahan pertimbangan pemerintah dalam melakukan putusan sidang isbat. ${ }^{12}$

Hasil sidang isbat disampaikan kepada publik oleh Menteri Agama. Isbat dilakukan dengan melewati berbagai pertimbangan, mulai dari data hisab dan hasil observasi (rukyat) yang merupakan hasil musyawarah Menteri Agama dengan anggota Tim Falakiah, ormas Islam dan para ahli. Disinilah keputusan sidang isbat memiliki peran penting bagi pemerintah untuk mengakomodir perbedaan di antara ormas-ormas Islam di Indonesia dan memberikan kepastian kepada umat Islam terkait dengan penetapan awal bulan Ramad'an, Syawal, dan Z|ulhijjah, menjadi solusi atas perbedaan selama ini. ${ }^{13}$

Persoalan penetapan awal bulan Hijriah di Indonesia secara umum bersifat desentralistik. Artinya, organisasi Islam masing-masing memiliki keputusan sesuai dengan metode dan kriteria yang telah ditetapkan. Dalam perkembangannya, penetapan kriteria yang diikuti oleh 5 organisasi besar Nahdlatul Ulama, Muhammadiyah, Persis, Al-Irsyad dan Al-Washliyah seringkali menghasilkan kesimpulan yang berbeda.

Meskipun ada sifat desentralisasi disana, tetapi negara juga turut hadir dan membuat keputusan tentang awal bulan Hijriah melalui sidang isbat. Sifat dari keputusan yang dikeluarkan oleh negara ini sesungguhnya tidak mengikat. Anggota dari organisasi kemasyarakatan yang kebetulan pandangannya berbeda dengan negara, biasanya mengikuti keputusan dari organisasinya, walaupun ada juga yang ikut pemerintah.

Dalam bagian latar belakang, penulis menjelaskan sebuah gambaran prediktif tentang kemungkinan terjadinya perbedaan penetapan awal bulan sebanyak 7 kali mulai tahun 2022 hingga 2035. Tawaran mengenai draf kriteria bersama penetapan awal bulan Hijriah baik menurut MUI maupun MABIMS, adalah ikhtiar untuk meminimalisir munculnya perbedaan pendapat tersebut. Sehingga, ekspektasi mengenai penyatuan kriteria bisa dilakukan oleh pemerintah, baik merujuk pada draf kriteria MUI atau MABIMS.

${ }^{12}$ Departemen Agama, Almanak Hisab Rukyat, (Jakarta: Direktorat jenderal Agama Islam 2010), 74 .

13 Keputusan Menteri Agama Republik Indonesia Nomor 64 Tahun 2016. Tentang Pembentukan Tim Hisab Rukyat Kementerian Agama. Lihat Slamet Hambali, "Fatwa Sidang Isbat dan Penyatuan Kalender Hijriah", (Makalah Lokakarya Internasional dan Call for Paper IAIN Walisongo Fakultas Syariah, Semarang, 12-13 Desember 2012), 8-9. 
Pertanyaanya kemudian yakni jika pemerintah mengeluarkan kebijakan mengenai penetapan awal bulan itu berarti ada intervensi terhadap keyakinan keagamaan warga negaranya?

Kriteria apapun yang nantinya digunakan negara, tentunya harus didasarkan pada kesepakatan dan kesepahaman bersama seluruh ormas Islam. Sehingga, ketika ada aturan yang dikeluarkan, merupakan rumusan bersama yang disepakati dan bersifat mengikat. Potensi konflik yang dimungkinkan terjadi, bisa diminimalisir. Sebaliknya, jika tidak tercapai kesepakatan diantara ahli falak ormas Islam, maka kebijakan terkait penetapan awal bulan Hijriah akan kembali seperti semula. Pemerintah hanya bisa memberikan himbauan dan ketetapan pemerintah yang tidak bersifat mengikat seperti yang sudah berjalan.

Hubungan negara dan agama, seperti yang tercermin dalam penetapan awal bulan Hijriah di Indonesia, menunjukkan relasi yang khas. Meski pada dasarnya keyakinan tentang awal bulan itu adalah hak otonom warga negara (salah satunya melalui ormas), tetapi negara mempunyai kewajiban untuk turut hadir meski dalam kapasitas mereka sebagai penyampai informasi dan penjaga kestabilan umat. Hasil akhir penelitian ini menunjukkan bahwa draf kriteria MUI dan MABIMS, akseptabel secara kuantitatif. Ini artinya, keputusan yang dibuat pemerintah, tidak hanya bersifat himbauan yang tak mengikat, tetapi peraturan yang mengikat. Sekali lagi, itu akan terjadi jika ahli falak ormas Islam telah terlebih dahulu menyetujuinya.

\section{Unifikasi kalender Hijriah di Indonesia}

Semangat unifikasi atas kalender Hijriah pada dasarnya telah tertanam dalam setiap benak umat Islam. Hal ini terlihat dengan banyaknya berbagai usaha penyatuan melalui berbagai pertemuan, musyawarah, seminar, lokakarya dan lain sebagainya. Citacita besar ini tidak akan terwujud jika masih ada perbedaan pendapat yang mengedepankan sebuah self-egoism dan self-fanatism seseorang, kelompok, ataupun negara yang mementingkan kehendaknya masing-masing. Semangat unifikasi ini telah dirancang sedemikian rupa oleh para pengamat dan pegiat ilmu falak dan astronomi, di mana yang sering dipakai dan dipergunakan adalah kriteria imkan rukyat. Indonesia sendiri ada beberapa konsep imkan rukyat yang berkembang dan dipublikasikan oleh para ahli.

Konsep imkan rukyat dengan ketinggian hilal 2 derajat adalah yang paling terkenal di masyarakat. Padahal hakikatnya konsep yang dipakai oleh Kementrian Agama dan 


\section{| AHMAD FADHOLI | Akseptabilitas Draf Kriteria Baru...}

MABIMS ini tidak hanya satu variabel, tetapi masih ada ketentuan elongasi minimal harus 3 derajat, serta umur bulan minimal 8 jam. Ketiganya saling berkaitan dan menjadi satu konsep kriteria pada penentuan awal bulan Hijriah. Walaupun demikian, konsep tersebut dianggap masih memiliki pekerjaan rumah yang harus diselesaikan. Salah satunya adalah masih dianggap jauh dari kata ideal pada tinjauan sebuah kajian visibilitas hilal yang ilmiah.

Berawal dari hal itu dan seiring berjalannya waktu, para cendekiawan ilmu falak mencoba membuat berbagai formula baru kriteria imkan rukyat yang paling ideal untuk keberlangsungan semangat unifikasi kalender Islam mulai dari tataran nasional, regional kawasan, sampai internasional. Hasil dari semangat tersebut, pada tahun-tahun belakangan ini muncul beberapa kriteria baru, yaitu kriteria yang diusung oleh Majelis Ulama Indonesia (MUI), dan regional kawasan yang di wakili dengan kriteria MABIMS.

Demi terwujudnya penyatuan kalender Hijriah, serasa memerlukan waktu yang sangat panjang dan persoalan yang tidak kunjung selesai. Persoalan ini tidak akan menemui sebuah kriteria tunggal apabila tidak ada kesepakatan serta tidak ada komitmen bersama untuk menggunakan dan melaksanakan apa yang telah disepakati. Setiap kriteria pasti ada kekurangan dan kelebihan yang akan digunakan. Maka yang harus dijunjung tinggi adalah nilai kemanfaatan terhadap persatuan umat Islam dan terjalinnya ukhuwah Islamiah, dan tentunya tanpa menafikan dalil syari dan ilmu pengetahuan.

Atas dasar inilah, seharusnya ormas Islam lebih mengedepankan dan menjunjung persatuan. Pembahasan dari data di atas pada dasarnya dari jawaban subyek secara keseluruhan belum memperlihatkan kesamaan untuk akseptabilitas sepenuhnya terhadap draf kriteria baru, namun ada niatan untuk bersatu. Niatan ini terlihat atas usulan kriteria yang pada hakikatnya mencari yang paling baik untuk dijadikan pedoman. Persoalan ini, yang harus disamakan dalam bingkai kebangsan, dengan melalui diskusi intensif untuk mencari titik temu, tentang persamaan pedoman kriteria penampakan hilal sebagai akibat dari penentuan awal bulan hijriah.

Sudah semestinya persoalan ini dicarikan solusinya, mengingat perkembangan ilmu pengetahuan sekarang masyarakat merasa resah jika terjadi perbedaan, dan akhirnya tidak lagi mengikuti keputusan ormas namun lebih mengikuti hasil sidang isbat. Ini menandakan pemerintah mempunyai andil besar dalam mempesatukan bangsa melalui keputusan yang diambil. Peran negara dengan mengambil kebijakan akan memperkecil 
perbedaan, jika ini terlambat maka akan berdampak besar mengingat persoalan ini adalah sangat sensitif karena menyangkut keyakinan dan identisas ormas.

Dari itu, maka perlu ada strategi khusus melalui pendekatan fikih-politikastronomi yang harapannya saling bersinergi, karena ini menyangkut persoalan fikih khusus yang dijadikan landasan melalui kesepakatan dengan menggunakan parameter kajian data astronomi yang melahirkan kriteria yang sesuai dan diharapkan. Dengan cara inilah gesekan dan perdebatan akan terminimalisir untuk kemaslahatan umat.

Meskipun demikian, tetap terdapat beberapa catatan masukan guna penyempurnaan draf dan beberapa yang tidak banyak mengambil sikap karena lebih condong pada ketetapan ormasnya. Jika penyempurnaan draf kriteria baru memang dilakukan, maka alangkah baiknya jika dilakukan dengan cara pengkajian dan penelitian yang kontinu sehingga bisa menghasilkan draf kriteria baru yang kompatibel sesuai dengan kajian syariat dan astronomi. Pendapat dan saran yang demikian juga disampaikan oleh subyek yang belum akseptabel. Mereka pun berpendapat tentang perlunya kajian yang komprehensif antara ormas Islam pemerintah dan para ilmuan falak dan astronomi.

Ini adalah hal yang wajar jika ada perbedaan, karena Indonesia negara demokrasi. Akan tetapi jika ada formula yang bisa menyatukan adalah hal yang menggembirakan sehingga akan meningkatkan persatuan dan meminimalisir perbedaan. Menyamakan persepsi diantara perbedaan karakteristik yang dimiliki ormas Islam di Indonesia bukanlah hal yang mudah. Semua itu akan ringan ketika semua ahli falak ormas tersebut memiliki persepsi yang sama tentang keberbangsaan, maka akan lebih soft reaksi ketimbang ego organisasi sehingga tidak menutup kemungkinan terbuka terhadap masukan bahkan bisa akseptabel bagi yang belum akseptabel terhadap draf kriteria karena didasarkan pada persatuan umat atau kemaslahatan. 


\section{DAFTAR PUSTAKA}

\section{Sumber buku}

Ali, Taqiuddin, Al-Ilmu al-Manshur Fi>. Itsbatis Syuhu>r, Kurdistan: Kurdistan al ilmiah, $1329 \mathrm{H}$.

Anwar, Syamsul, Diskusi \& Korespondensi Kalender Hijriah Global, Yogyakarta: Suara Muahmmadiyah, 2014.

,Interkoneksi Studi Hadis dan Astronomi, Yogyakarta: Suara Muhammadiyah, 2011.

Azhari, Susiknan,Kalender Islam ke Arah Integrasi Muhammadiyah-NU,Yogyakarta: Museum Astronomi Islam, 2012.

Hisab dan Rukyat Wacana untuk Membangun Kebersamaan di Tengah Perbedaan, Yogyakarta: Pustaka Pelajar, 2008.

Departemen Agama RI, Almanak Hisab Rukyat, Jakarta: Direktorat Jenderal Pembinaan Kelembagaan Agama Islam, 1998/1999.

Djamaluddin, Thomas,Astronomi Memberi Solusi Penyatuan Umat, Bandung: LAPAN, 2011.

Menggagas Fikih Astronomi: Tela'ah Hisab Rukyat dan Pencarian Solusi Perbedaan Hari Raya, Bandung: Penerbit Kaki Langit, 2005.

Menjajah Keluasan Lagit Menembus Kedalaman al-Qur'an, Bandung: Hasanah Intelektual, 2006.

Hasan, Muhammad, Imka>nar-Ru'yah di Indonesia (Memadukan Perspektif Fiqih dan Astronomi), Disertasi tidak diterbitkan, Semarang: IAIN Walisongo, 2012.

Izzuddin, Ahmad, Fiqh Hisab Rukyah Di Indonesia (Sebuah upaya Penyatuan Madzhab Rukyah dengan Madzhab Hisab), Jakarta: Erlangga, 2007.

Kementerian Agama RI, "Keputusan Menteri Agama RI 1 Ramad;an, Syawal dan Z|ulhijjah 1381 H-1432 H/1962 M-2011 M", Jakarta: Direktorat Urusan Agama Islam dan Pembinaan Syariah, 2011.

Keputusan PBNU ini telah dijadikan suatu buku yang berjudul "Pedoman Rukyat dan Hisab” diterbitkan oleh Sekretariat Jendral PBNU tahun 1994 M. 
Lembaga Falakiyah PBNU, Pandangan Nahdlatul Ulama Tentang Usulan Kalender Hijriyah Tunggal dan Usulan Kriteria ImkanuRukyah MABIMS Baru (Surat Pandangan), Jakarta 27 Nopember 2017.

Majelis Tarjih dan Tajdid Pimpinan Pusat Muhammadiyah, Pedoman Hisab Muhammadiyah, Yogyakarta: Majelis Tarjih dan Tajdid Pimpinan Pusat Muhammadiyah, 2009.

Pengurus Besar Nahdlatul Ulama, Hasil Mukatamar Nahdlatul Ulama ke 27 Situbondo, Semarang: Sumber Barokah, 1985.

Pengurus Pusat Muhammadiyah, Himpunan Putusan Majelis Tarjih Muhammadiyah,Yogyakarta:PP Muhammadiyah, tt.

Pimpinan Pusat Muhammadiyah, Tanfidz Keputusan Muktamar Muhammadiyah Ke-47, Yogyakarta: Pimpinan Pusat Muhammadiyah, 2015.

Rahman, Abdur, Bughyatul Mustarsyidin fi $>$ taklhi $>$ si fata $>$ wa $>$ ba'di al-aimmati min almutaakhirina $>$, Yaman Tari $>$ m:Da $>$ r al-Faqi $>$ h, 2009.

Saksono, Tono, Mengkompromikan Rukyat dan Hisab,Jakarta: Amythas Publicita, 2007.

Tim Majelis Tarjih dan Tajdid PP Muhammadiyah, Fatwa-fatwa Tarjih: Tanya Jawab Agama, Yogyakarta: Suara Muhammadiyah, 2013.

\section{Sumber Jurnal}

Anwar, Syamsul, "Tindak Lanjut Kalender Hijriah Global Turki 2016 Tinjauan Usul Fikih", JurnalTarjih dan Tajdid, Volume13 Nomor 2, (2016): 99-124.

Azhari, Susiknan, "Gagasan Penyatuan Umat Islam Indonesia Melalui Kalender Islam”,Jurnal Ahkam,Vol. XV, No. 2, Juli 2015: 249-258.

Azhari, Susiknan, "Karakteristik Hubungan Muhammadiyah dan NU dalam Menggunakan Hisab dan Rukyat”,Jurnal Al-Ja>mi'ah, vol. 44. no. 2, 2006 M/1427 H.

\section{Sumber lain}

Ahmad Hakim, Syarief, “Sekilas Sejarah Almanak Persis”, Jakarta: tp, 2013.

Azhari, Susiknan, "Penyatuan Kalender Islam Satukan Semangat Membangun Kebersamaan Umat", Lokakarya Internasional dan Call for Paper, Semarang: IAIN Walisongo Fakultas Syariah, 12-13 Desember 2012.

"Kalender Hijriyah Bisa Memberi Kepastian Setara dengan Kalender Masehi Lokakarya Internasional dan Call for Paper, Semarang: IAIN Walisongo Fakultas Syariah, 12-13 Desember 2012. 
, "Visibilitas Hilal: Titik Temu Hisab dan Rukyat", Diklat Nasional II Hisab dan Rukyat, Jepara: LFPB NU, 4-8 September 2002.

Menuju Penyatuan Kalender Islam Di Indonesia, yang disampaikan pada acara Seminar Nasional dan Launching Program Studi Al-Ahwal Al-Syakhsiyyah Konsentrasi Ilmu Falak Fakultas Syari'ah IAIN Walisongo Semarang pada tanggal 9 Agustus 2007 di Auditorium I 1t.2 IAIN Walisongo-Semarang.

Fatwa MUI Nomor 2 tahun2004.

Hambali, Slamet, "Fatwa, Sidang Isbat dan Penyatuan Kalender Hijriyah", Lokakarya Internasional dan Call for paper di Fakultas Syariah IAIN Walisongo, Semarang, tanggal 12-13 Desember 2012.

Iqbal Santoso, Mohammad "Hisab Imkanur-Rukyat Kriteria Awal Bulan Hijriyyah Persatuan Islam”, Garut, Jumadil-ula 1433H /April 2012M.,

Izzuddin, Ahmad, "Kesepakatan untuk Kebersamaan, Sebuah Syarat Mutlak Menuju Unifikasi Kalender Hijriyah", Lokakarya Internasional dan Call for paper di Fakultas Syariah IAIN Walisongo, Semarang, tanggal 12-13 Desember 2012.

Keputusan Musyawarah Nasional XXV Tarjih Muhammadiyah, 2000 M.

Keputusan Dewan Hisbah, Dewan Hisbah Persatuan Islam, Pada Sidang Kedua Pasca Muktamar XII di Ciganitri 1422 H, 2001 M.

Keputusan Bersama Dewan Hisab dan Rukyat dengan Dewan Hisbah No. 005/PPC.1/A.3/2012 dan No : 019/PP-C.1/A.2/2012 M

Keputusan Dewan Hisbah,Dewan Hisbah Persatuan Islam,pada sidang kedua Pasca Muktamar XII di Pesantren Persis Ciganitri, Jawa Barat, pada Sabtu Pon, 24 Rabiul Awwal 1422 H/16 Juni 2001 M.,

putusan VII Surat Keputusan Dewan Hisbah, pasca muktamar XII di Pesantren Persis Ciganitri 24 Rabiul. Awwal 1422 H/16 Juni 2001 M.

Musyawarah Nasional Tarjih Ke-26, 2003 M

Raharto, Moedji, "Kalendar Islam: Sebuah Kebutuhan dan Harapan "Muzakarah Tentang Hisab Rukyat dalam Penyatuan Awal Ramadhan dan Syawal 1434 H", Jakarta: Universitas Al-Azhar, 8 Juni 2013.

\section{Sumber Internet}

al-Irsyad Al-Islamiyyah, "Tentang Al-Irsyad”, diakses 6 November 2017., http://alirsyad.net/tentang-al-irsyad/. 
, "Surat Keputusan Al-Irsyad Al-Irsyad No. 96-SK-1433 hasil hisab AlIrsyad", diakses pada tanggal 6 November 2017, http://alirsyad.net/tentang-alirsyad/.

Azhari, Susiknan, "Visibilitas Hilal MABIMS dan Implementasinya", diakses 5 Oktober 2017, http://museumastronomi.com/hasil-muzakarah-mabims-dan-masa-depankalender-islam-global/.

Direktorat Jenderal Bimbingan Masyarakat Islam, "Agenda Muzakarah dan Takwim Islam Negara Anggota Mabims 2016", diakses 5 Oktober 2017,http://bimasislam.kemenag.go.id/post/berita/ini-agenda-muzakarah-dantakwim-islam-negara-anggota-mabims-2016-.

Djamaluddin, Thomas, "Kongres Kesatuan Kalender Hijri Internasional di Turki 2016: Kalender Tunggal" diakses 26 September 2016, http//tdjamaluddin.wodpres.

"Lokakarya Kriteria Awal Bulan: Perwakilan Ormas Islam Bersepakat", diakses 5 Oktober 2017, http//tdjamaluddin.wordpress.com.

,"Menuju Kriteria Baru MABIMS Berbasis Astronomi“" diakses 26 September 2016, http//tdjamaluddin.wodpres.

"Naskah Akademik Usulan Kriteria Astronomis Penentuan Awal Bulan Hijriyah" diakses 26 September 2016, http//tdjamaluddin.wodpres.

Kabar Washliyah, "Suara Al Washliyah Dalam Sidang Itsbat”, diakses 6 November 2017, http://kabarwashliyah.com/2015/09/22/suara-al-washliyah-dalam-sidang-itsbat/.

“Al Washliyah Tetapkan 1 Ramadhan Jatuh Pada Hari Kamis 18 Juni 2015", diakses 6 November 2017, http://kabarwashliyah.com/2015/05/28/al-washliyahtetapkan-1-ramadhan-jatuh-pada-hari-kamis-18-juni/.

"Al Washliyah Tetapkan 1 Ramadhan 1437 H Jatuh Pada 6 Juni" diakses 6 November 2017, http://kabarwashliyah.com/2016/05/08/al-washliyah-tetapkan-1ramadhan-1437-h-jatuh-pada-6-juni/.

Keputusan Bersama Dewan Hisab dan Rukyat dengan Dewan Hisbah No. 005/PPC.1/A.3/2012 dan No : 019/PP-C.1/A.2/2012 tentang Kriteria Imakanur Rukyah Persis, diakses 7 Oktober 2017, http://persisjakarta.com/kronologis-keputusan-pppersis-tentang-penetapan-idul-fitri-1438-h/

MABIMS, "Mesyuarat Pegawai-Pegawai Kanan (SOM) Kali Ke-40 bagi MABIMS", $\begin{array}{llll}\text { diakses } & 5 & \text { Oktober } & \text { 2017, }\end{array}$ http://www.emabims.org/Lists/Berita/DispItemForm.aspx?ID=23.

"Tentang MABIMS", diakses 5 Oktober 2017, http://www.emabims.org/SitePages/tentang-mabims.aspx. 
| AHMAD FADHOLI | Akseptabilitas Draf Kriteria Baru...

Majelis Tarjih dan Tajdid Pimpinan Pusat Muhammadiyah, "Kongres Kalender Turki Akhirnya Tetapkan Konsep Unifikatif Sebagai Kalender Dunia Islam” diakses 26 September 2016, http://tarjih.or.id/kongres-kalender-turki-akhirnya-tetapkankonsep-unifikatif- 